\title{
Prediction of intramammary infection status across the dry period from lifetime cow records
}

\author{
A. C. Henderson, ${ }^{* 1}$ C. D. Hudson, ${ }^{*}$ A. J. Bradley, ${ }^{*} \dagger$ V. E. Sherwin, ${ }^{*}$ and M. J. Green ${ }^{*}$ \\ *School of Veterinary Medicine and Science, Sutton Bonington Campus, University of Nottingham, Sutton Bonington, Leicestershire, \\ LE12 5RD, United Kingdom \\ †Quality Milk Management Services Ltd., Cedar Barn, Easton Hill, Easton, Nr Wells, Somerset, BA5 1DU, United Kingdom
}

\begin{abstract}
The dry period is very important for mammary gland health, with the aim not only to cure existing intramammary infections (IMI) but also to prevent new IMI. Although it is known that the dry period is an important time for optimizing udder health, the probability that individual cows will succumb to a new IMI or, if infected, will fail to cure an IMI is not well established. The aim of this study was to investigate whether lifetime cow data, available through routine on-farm milk recording, could be used to predict changes in IMI status across the dry period for individual cows that were (1) deemed high somatic cell count (SCC; $>199,000$ cells/ $\mathrm{mL})$ or $(2)$ low $\mathrm{SCC}(<200,000$ cells $/ \mathrm{mL})$ at the last test day before drying off. Milk recording data collected between September 1994 and July 2014 from 114 herds in the United Kingdom were used. Two 2-level random effects models were built and both cure and new IMI were used as outcome variables in separate models. Cows with a smaller proportion of test days with a high SCC in the lactation before drying off, a smaller proportion of test days recording a high SCC in the lactation before the current lactation, of lower parity, producing less milk before drying off, of lower days in milk at drying off, and of lower SCC just before drying off were more likely to cure across the dry period. Dry period length had no effect on the likelihood of cure. Individual cows with a smaller proportion of test days recording a high SCC in the lactation before the current, of lower parity, of lower milk production at drying off, and fewer days in milk at drying off were less likely to develop a new IMI. Dry period length was found to have no effect on the probability of new IMI. Model predictions showed that a high level of discrimination
\end{abstract}

Received November 25, 2015.

Accepted March 4, 2016.

${ }^{1}$ Corresponding author: stxah14@nottingham.ac.uk was possible between cows with a high and low risk of both cures and new infections across the dry period.

Key words: dry period, cure, new infection, somatic cell count, mastitis

\section{INTRODUCTION}

Mastitis is the most common and costly endemic disease that affects the United Kingdom and worldwide dairy industries (Rajala-Schultz et al., 1999; Whist and Osterås, 2007; Farm Animal Welfare Council, 2009). Mastitis has been estimated to represent $38 \%$ of all direct costs associated with production disease, causes annual production losses of $£ 170$ million in the United Kingdom and $\$ 2$ billion in the United States (Kossaibati and Esslemont, 1997; Coffey et al., 2006; Rajala-Schultz et al., 2011).

The dry period is an important time for optimizing udder health and milk quality with; the aim of cure of existing IMI and preventing the acquisition of new IMI (Eberhart, 1986; Bradley and Green, 2000; Dingwell et al., 2004). It is well established that new IMI may be acquired during the dry period and that these have a negative effect on udder health in the subsequent lactation (Bradley and Green, 2000; Green et al., 2002; Pantoja et al., 2009). New IMI present at the first test day of a new lactation can have significant financial implications as a result of deleterious effects on milk yield, quality, and further implications in terms of antimicrobial use and dairy cow welfare (Bradley and Green, 2000; Archer et al., 2013a,b, 2014).

The transition of SCC from last test day before drying off to first test day after calving has been reported to be a useful method to assess performance of individuals and groups across the dry period (Cook et al., 2002; Whist and Osterås, 2007). Prediction of risk profiles for individuals or groups of cows would be of particular interest because appropriate management practices could be targeted toward these animals. This may include alteration of the environment (Green et 
al., 2007, 2008), changing dry cow therapy (Halasa et al., 2009a,b), or culling and segregation of animals with a remote likelihood of cure in the subsequent lactation. Some cow-level risk factors for cure of IMI have been reported and include number of quarters infected, age, SCC, and dry period length (Osterås et al., 1999; Dingwell et al., 2003; Church et al., 2008). Risk factors for new IMI at the cow level have also been identified, including milk yield at drying off, parity, and dry period length (Huxley et al., 2002; Dingwell et al., 2004; Church et al., 2008). Previous studies have shown SCC $<200,000$ cells $/ \mathrm{mL}$ within $90 \mathrm{~d}$ before drying off to be significantly associated with reduced risk of clinical and subclinical mastitis in the next lactation (Green et al., 2007, 2008). The best association between composite SCC at drying off and future composite SCC in the next lactation was found using at least 2 test days before drying off (Whist and Osterås, 2007). An individual cow's probability of failure to cure has been estimated at the point of drying off and highlighted that the geometric mean natural log of the last 3 test days for composite SCC had the best association with the probability of failure (Osterås et al., 1999). However, no studies have used full lifetime cow records and SCC to create a risk profile for dry period outcomes at the point of drying off. The purpose of the current study was to investigate whether historic lifetime data, available through routine on-farm recording, could be used to predict changes in IMI status across the dry period for individual cows.

\section{MATERIALS AND METHODS}

\section{Data}

This retrospective cohort study comprised a large convenience sample of anonymized milk recording data collected by a milk recording organization (Quality Milk Management Services, Easton, UK) in the United Kingdom between September 1994 and July 2014.

The data were checked for erroneous data points and test days with missing values were recorded as missing. Data sorting was performed using Microsoft Access 2010 (Microsoft Corp., Redmond, WA) and the final data set prepared for statistical analysis using Microsoft Excel 2010.

All farms undertook milk recording on a monthly basis. Lactations were only included in the data set if they had at least 6 test days per lactation (including first test day and at least monthly herd tests for the last 5 mo before drying off) and the first test day of the next lactation (to allow assessment of dry period infection status). The last 5 test days were selected in blocks of 0 to 30,31 to 60,61 to 90,91 to 120 , and 121 to $150 \mathrm{~d}$ be- fore drying off; if 2 recordings occurred within a single one of these time frames the one closest to drying off was used. The first test day of the next lactation was selected to occur at less than 40 DIM; if 2 recordings occurred within this interval the one closest to calving was taken. The final data set included records of 46,257 lactations from 24,570 cows in 114 herds.

An SCC <200,000 cells/mL was classified as uninfected, and SCC >199,000 cells/mL was classified as infected (McDermott et al., 1982; Dohoo and Leslie, 1991; Schepers et al., 1997). The proportion of test days infected in any 1 lactation was calculated from the number of test days infected divided by the total number of test days in the lactation. Different SCC thresholds were investigated using those reported in the model. Lactations were then categorized into a variable comprising the proportion of test days infected in each lactation, using the following categories: 0,1 to 25,26 to 50,51 to 75 , and 76 to $100 \%$. The maximum of the last 5 test days SCC recording was also grouped into a categorical variable using the following categories: 0 to $20,000,21,000$ to $30,000,31,000$ to $50,000,51,000$ to $70,000,71,000$ to $90,000,91,000$ to $150,000,151,000$ to 199,000 , and $>199,000$ cells $/ \mathrm{mL}$.

Dry periods were classified as eligible for new infection depending on the last SCC before drying off: SCC $<200,000$ cells $/ \mathrm{mL}$ and eligible for cure or SCC $>199,000$ cells $/ \mathrm{mL}$. Binary variables were created to represent the outcome for each dry period: for dry periods eligible for a new infection, the outcome was either 1 (where the first test day had a SCC >199,000 cells $/ \mathrm{mL}$ ) or 0 (where the first test day had a SCC $\leq 199,000$ cells/mL). For dry periods eligible for cure, the outcome was classified as a 1 (where the first test day had a SCC $<200,000$ cells $/ \mathrm{mL}$ ) or 0 (where the first test day had a SCC $\geq 200,000$ cells $/ \mathrm{mL}$ ).

\section{Descriptive Analysis}

An exploratory analysis of the data was carried out to identify patterns within the data. Descriptive statistics was performed using Microsoft Excel 2010 (Microsoft Corp.) and R (R Core Team, 2015).

\section{Statistical Analysis}

Model 1: Probability of Cure of IMI. A multilevel (random effects) logistic regression model was constructed for the outcome variable cure of IMI to explore the associations between this outcome and historical cow-level variables (Table 1). A 3-level random effects model with lactations nested within cows nested within herds was used. The model took the form: 
Table 1. Model 1: Potential predictor variables tested in the cure of IMI model

\begin{tabular}{ll}
\hline Potential predictor variable & Variable type \\
\hline Proportion of prior lactation $>199,000$ cells $/ \mathrm{mL}$ & Categorical \\
Proportion of prior lactation $>399,000$ cells $/ \mathrm{mL}$ & Categorical \\
Proportion of prior lactation $>599,000$ cells $/ \mathrm{mL}$ & Categorical \\
Proportion of lactation before current $>199,000$ cells $/ \mathrm{mL}$ & Categorical \\
Proportion of lactation before current $>399,000$ cells $/ \mathrm{mL}$ & Categorical \\
Proportion of lactation before current $>599,000$ cells $/ \mathrm{mL}$ & Categorical \\
Parity & Categorical $(1,2,3,4, \geq 5)$ \\
Milk yield at last test day $(\mathrm{kg})$ & Continuous \\
Lactation length $(\mathrm{d})$ & Continuous \\
Dry period length $(\mathrm{d})$ & Continuous \\
SCC at last test day $(100,000$ cells $/ \mathrm{mL})$ & Continuous \\
\hline
\end{tabular}

${ }^{1}$ Parity $\geq 5=$ includes parity $5-16$.

$$
\begin{gathered}
\operatorname{CureIMI}_{i j k} \sim \text { Bernoulli }\left(\text { mean }=\pi_{i j k}\right), \\
\operatorname{logit}\left(\pi_{i j k}\right)=\alpha+\beta_{1} \mathrm{X}_{i j k}+\beta_{2} \mathrm{X}_{j k}+u_{j k}+v_{k}, \\
u_{j k} \sim N\left(0, \sigma_{u}^{2}\right), \\
v_{k} \sim N\left(0, \sigma_{v}^{2}\right),
\end{gathered}
$$

where the subscripts $i, j$, and $k$ represent the $i$ th cow lactation in the $j$ th cow in the $k$ th herd, respectively; $\pi_{i j k}$ is the probability of cure of IMI for the $i$ th cow lactation in the $j$ th cow of the $k$ th herd; $\alpha$ is the model intercept; $\mathrm{X}_{i j k}$ and $\mathrm{X}_{j k}$ are predictor variables at lactation and cow level and $\beta_{1}$ and $\beta_{2}$ the coefficients for $\mathrm{X}_{i j k}$ and $\mathrm{X}_{j k} ; u_{j k}$ was a random effect to account for the residual variation between cows within herds and $v_{k}$ the residual variation between herds (both assumed to be normally distributed with mean $=0$ and variances $=$ $\sigma_{u}^{2}$ and $\sigma_{v}^{2}$, respectively).

The model was built using a forward selection procedure, with the retention of variables that were deemed significant (95\% credible intervals for the odds ratio did not include 1). Polynomials for continuous predictor variables were tested and were retained in the model when significant. This was important to test, as it was biologically plausible to have nonlinear relationships for these variables.
Initial model building was carried out in MLwiN version 2.32 (Rabash et al., 2015). Final parameter estimates were made in a Bayesian framework using Markov chain Monte Carlo with a burn-in chain length of 5,000 iterations (to ensure convergence) and a monitoring chain length of 50,000 iterations. Model building and assessment of fit was conducted using techniques described previously (Green et al., 2004). Posterior predictions (Gelman et al., 1996) were used to examine model fit and illustrate differences in expected cure rates between different subsets of cows. Model fit was found to be poorer with cow-level random effects included, and therefore final models consisted of a 2-level structure without the cow-level random effects (i.e., cow lactations within herds).

Model 2: Probability of New IMI. A multilevel logistic regression model was specified for cows eligible for a new IMI (Table 2). The approach to modeling was the same as that described for Model 1, with the final model consisting of a 2-level structure except the binary outcome was either new infection (1) or not (0).

\section{RESULTS}

\section{Descriptive Results}

All Data. The final data set used for analysis comprised 46,257 lactations, 24,570 cows, and 114 herds. The median DIM at drying off was 326 [interquartile

Table 2. Model 2: Potential predictor variables tested in the new IMI model

\begin{tabular}{ll}
\hline Potential predictor variable & Variable type \\
\hline Proportion of lactation before current $>199,000$ cells $/ \mathrm{mL}$ & Categorical \\
Parity ${ }^{1}$ & Categorical $(1,2,3,4, \geq 5)$ \\
Milk yield at last test day $(\mathrm{kg})$ & Continuous \\
Lactation length $(\mathrm{d})$ & Continuous \\
Dry period length $(\mathrm{d})$ & Continuous \\
Max SCC of last 5 test days ${ }^{2}$ & Categorical \\
\hline${ }^{1}$ Parity $\geq 5=$ includes parity $5-16$. & \\
${ }^{2}$ Maximum SCC of last 5 test days $=$ the categorized maximum SCC of the last 5 test days before drying off.
\end{tabular}



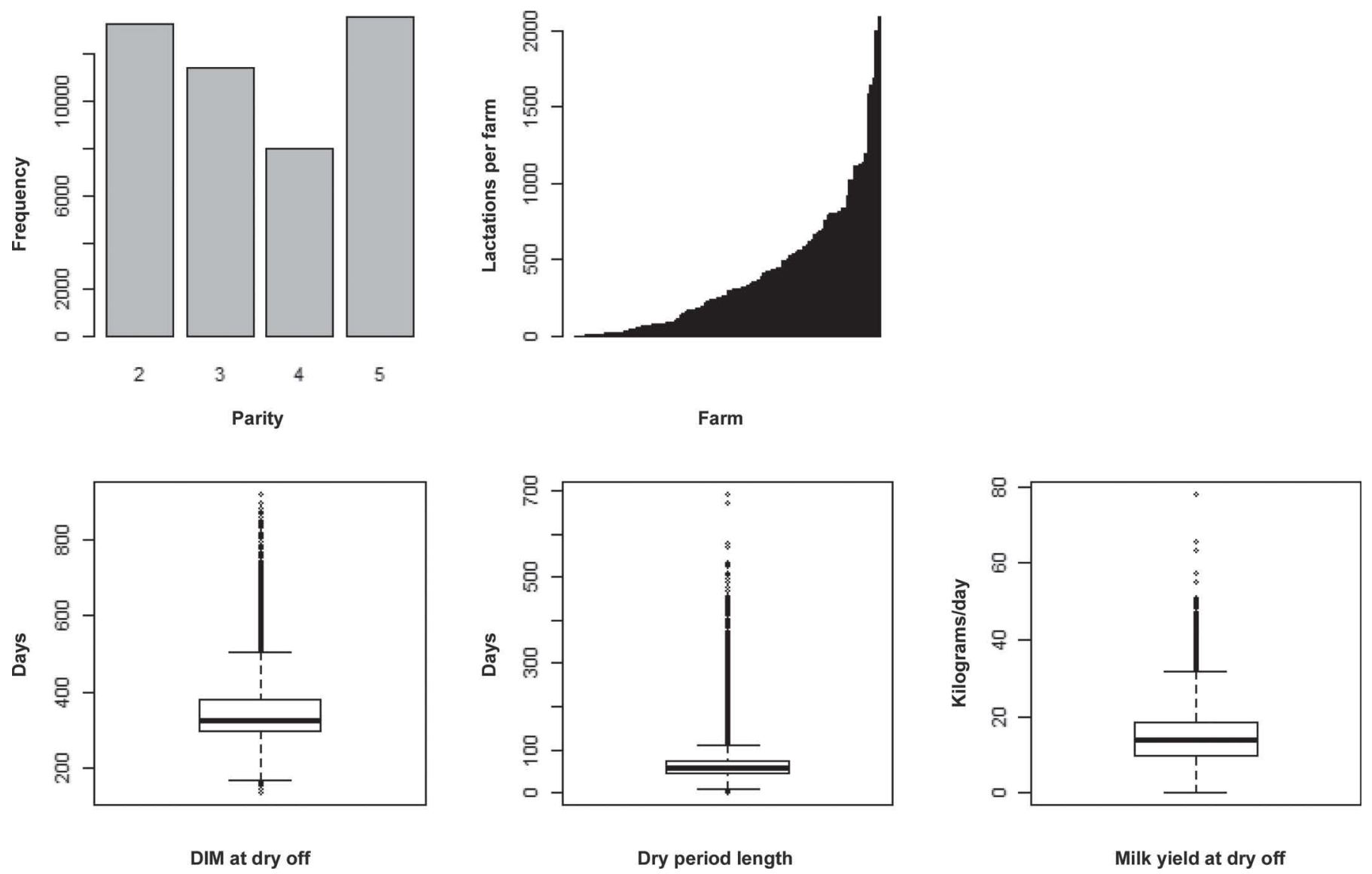

Figure 1. Descriptive results (all data): Distribution of a selection of variables including frequency of each parity, number of lactations per farm, DIM, dry period length (d), and milk yield at drying off ( $\mathrm{kg}$ ) from the 46,257 lactations from 24,660 cows in 114 herds between September 1994 and July 2014

range $(\mathbf{I Q R})=295-379]$, the median dry period length $($ DPL) was $58 \mathrm{~d}(\mathrm{IQR}=48-73)$, and the median milk yield (MY) in the month before drying off was $14 \mathrm{~kg}$ $(\mathrm{IQR}=9.8-18.5)$. The median parity was $3(\mathrm{IQR}=$ $2-5$ ), with the modal parity being 2 . The median number of lactations per farm was 280 (IQR $=75-580$ ). The median number of test days per lactation was 11 $(\mathrm{IQR}=9-12)$, with the modal number of test days per lactation being 10 (Figure 1).

Cows Eligible for Cure. Cows eligible for IMI cure originated from all 114 herds and data were available for 20,109 lactations from 13,039 cows with 14,253 lactations from 10,170 cows achieving cure of IMI and 5,856 lactations from 4,397 cows failing to cure IMI. The median number of lactations per farm was 128 $(\mathrm{IQR}=30-226 ;$ Figure 2).

The median DIM at drying off was $333(\mathrm{IQR}=299$ 392) for all eligible lactations. The group achieving cure of IMI had a median DIM at drying off of 332 (IQR = 299-390), showing little difference from the group failing to achieve cure of IMI, which had a median of 338
$(\mathrm{IQR}=300-400)$. The median DPL was $61 \mathrm{~d}(\mathrm{IQR}=$ 50-83). The subset of dry periods achieving cure of IMI had a median DPL of $61 \mathrm{~d}(\mathrm{IQR}=50-81)$, with the group failing to cure IMI being similar with a median of $61 \mathrm{~d}$ (IQR $=48-88)$. Those eligible for cure had a median MY of $11.4 \mathrm{~kg}(\mathrm{IQR}=7.5-16.0)$; those achieving cure of IMI had a median MY at dry off of $11.2 \mathrm{~kg}$ $(\mathrm{IQR}=7.2-15.8)$, very similar to those failing to cure IMI, which had a median of $11.7 \mathrm{~kg}(\mathrm{IQR}=8.2-16.6)$

The median parity for those eligible for cure was higher than for those achieving cure of IMI. Those eligible had a median parity of $6(\mathrm{IQR}=3-6)$, with the modal being parity 3 , and those achieving cure IMI had a median parity of $4(\mathrm{IQR}=3-5)$, with the modal parity being 3 . Again, this showed very little difference with those failing to achieve cure of IMI, which had a median parity of $4(\mathrm{IQR}=3-6)$ and mode of 3 . The mean cure of IMI across all herds was $71 \%$, median $72 \%$ $(\mathrm{IQR}=66-79 \%)$.

Cows Eligible for New IMI. Cows eligible for new IMI originated from all 114 herds, and data were 

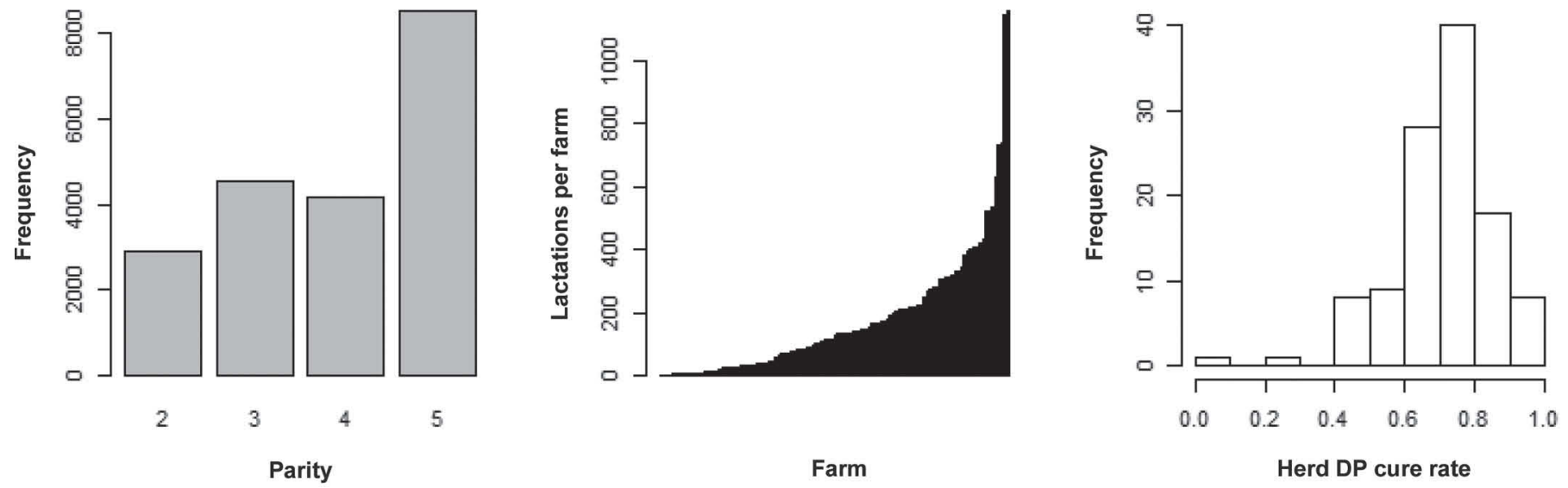

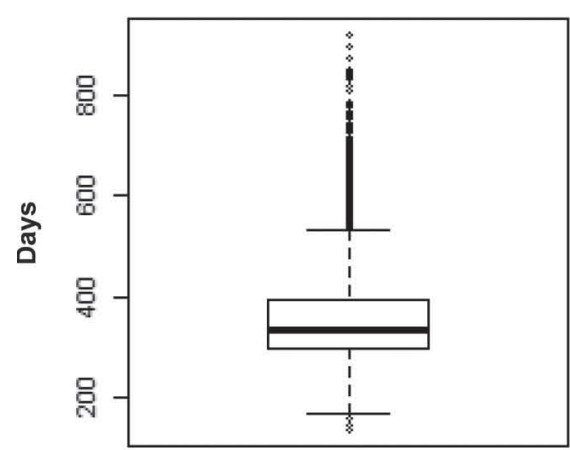

DIM at dry off

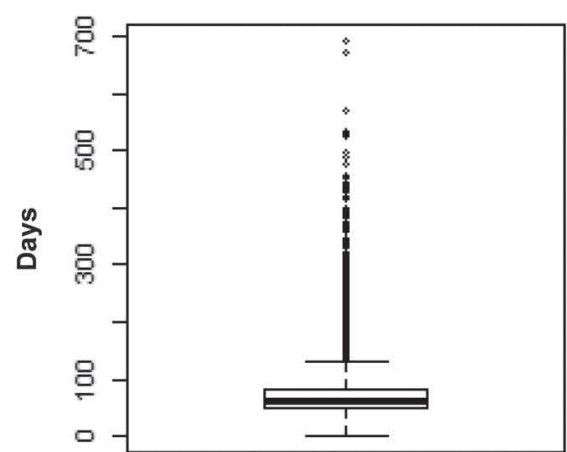

Dry period length

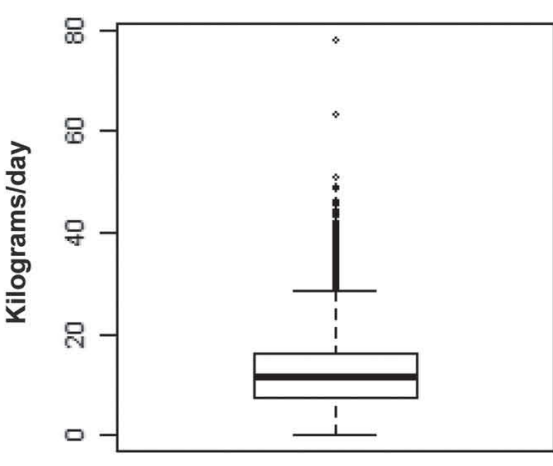

Milk yield at dry off

Figure 2. Descriptive results (cows eligible for cure): Distribution of a selection of variables including frequency of each parity, number of lactations per farm, DIM, dry period length (d), and milk yield at drying off (kg) and herd dry period (DP) cure rate from 20,109 lactations from 13,039 cows in 114 herds between September 1994 and July 2014.

available for 26,148 lactations from 17,100 cows. The median number of lactations per farm was 156 (IQR = 43-327; Figure 3). The subset succumbing to a new IMI included 4,718 lactations from 3,883 cows and those remaining uninfected included 21,430 lactations from 14,701 cows. The eligible population had a median DIM at drying off of 321 (IQR $=294-368)$; this was slightly longer for the subset acquiring a new IMI, with a median DIM at drying off of 326 (IQR $=296-376$ ), though shorter for those remaining uninfected, which had a median of $320(\mathrm{IQR}=293-366)$. No difference was evident in median DPL, with the group eligible for new IMI median DPL being $57 \mathrm{~d}$ (IQR 47 - 68), those acquiring new IMI having a median DPL of $57 \mathrm{~d}$ $(\mathrm{IQR}=45-69)$ and those remaining uninfected, which had a median of $57 \mathrm{~d}$ (IQR $48-68)$. Median MY at dry off showed very little difference with values of 15.9 $\mathrm{kg}(\mathrm{IQR}=12.0-20.0), 16.1 \mathrm{~kg}(\mathrm{IQR}=11.9-20.3)$, and $15.8 \mathrm{~kg}(\mathrm{IQR}=12-19.9)$ for those eligible for new IMI, acquiring new IMI, and remaining uninfected, respec- tively. The median parity was $3(\mathrm{IQR}=2-4)$ with the modal being parity 2 for the group eligible for new IMI (Figure 3 ); the median parity was $3(\mathrm{IQR}=2-5)$ with the modal being parity 2 for those acquiring new IMI, highlighting very little difference. The mean percentage of new IMI was 19\%, median $18 \%$ (IQR $=13-24 \%$ ).

\section{Statistical Modeling}

Model 1: Cure of IMI. The results of this model are presented in Table 3 . The probability of cure in a cow was significantly reduced with an increasing proportion of the prior lactation individual SCC >199,000 cells $/ \mathrm{mL}$ and additionally reduced with an increasing proportion of the prior lactation individual SCC $>399,000$ cells $/ \mathrm{mL}$. The odds of cure were more than 2 times higher [odds ratio $(\mathbf{O R})=2.59,2.22-3.03$ ] if $\leq 25 \%$ of the previous lactation was $>199,000$ cells $/ \mathrm{mL}$ compared with a lactation when $>75 \%$ were $>199,000$ cells $/ \mathrm{mL}$. The odds of cure was less than 2 times (OR 

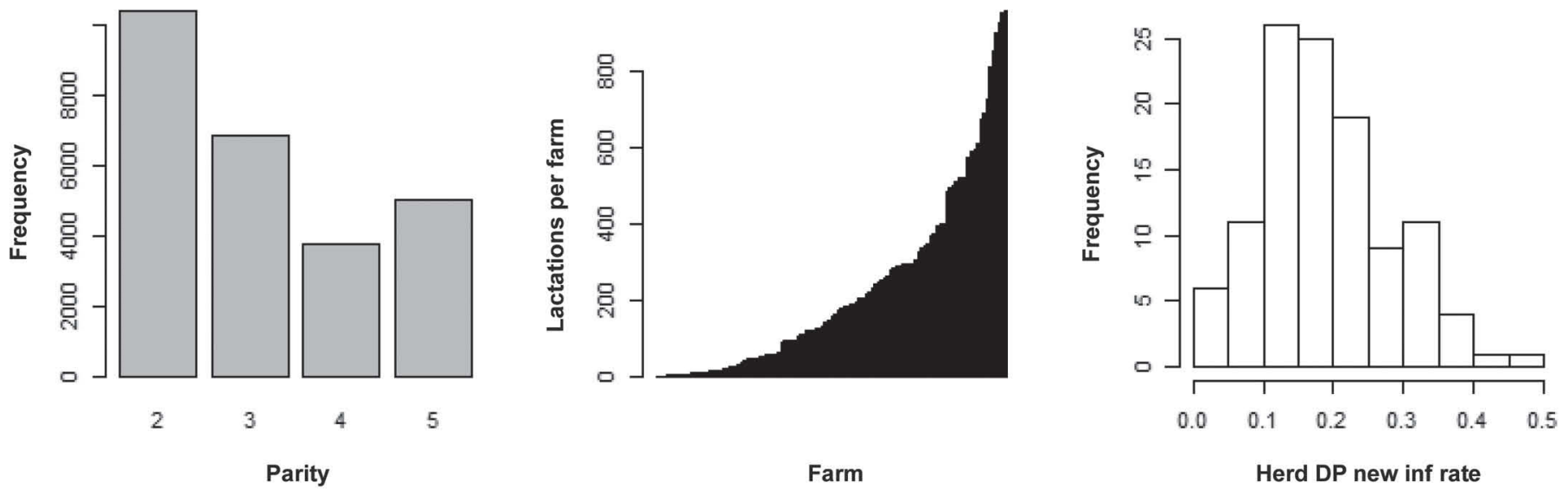

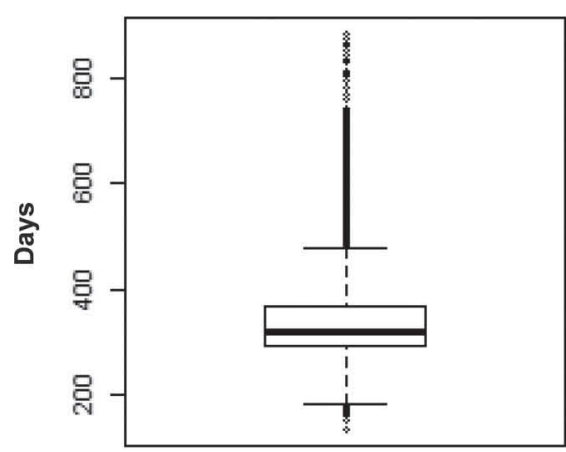

DIM at dry off

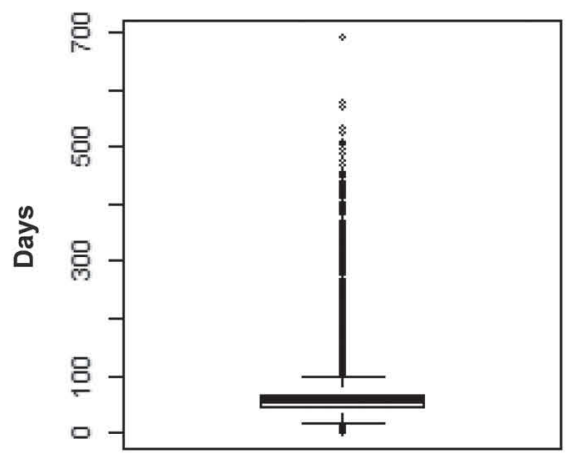

Dry period length

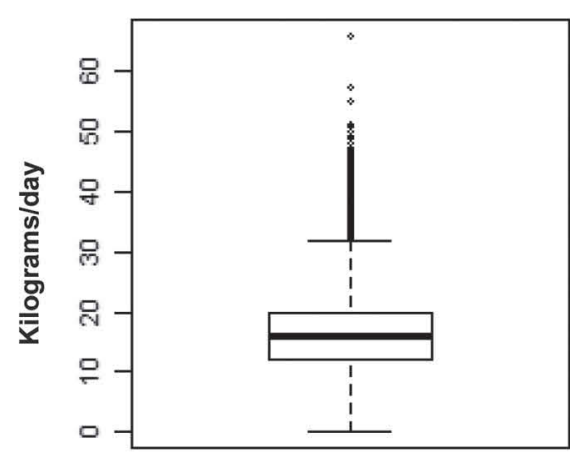

Milk yield at dry off

Figure 3. Descriptive results (cows eligible for new IMI): Distribution of a selection of variables including frequency of each parity, number of lactations per farm, DIM, dry period length (d), and milk yield at drying off $(\mathrm{kg})$ and herd dry period (DP) new infection rate from 26,148 lactations from 17,100 cows in 114 herds between September 1994 and July 2014.

Table 3. Model 1: Results of the multilevel logistic regression model for the probability of cure of IMI in an individual cow across the dry period

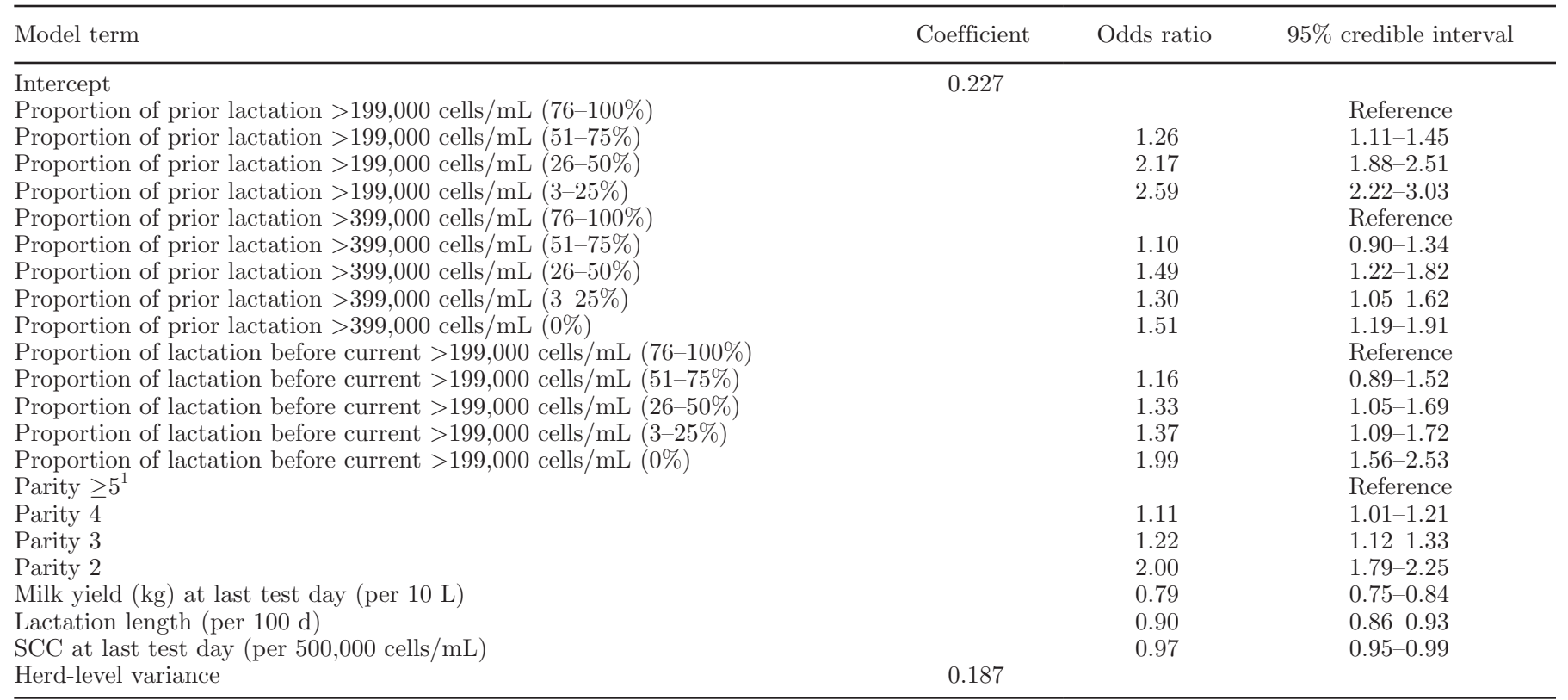

\footnotetext{
${ }^{1}$ Parity $\geq 5=$ includes parity $5-16$.
} 
$=1.30,1.05-1.62)$ higher when $\leq 25 \%$ of the prior lactation individual SCC were $>399,000$ cells $/ \mathrm{mL}$ compared with when $>75 \%$ of SCC were above this value.

The probability of cure decreased as the proportion of SCC $>199,000$ cells $/ \mathrm{mL}$ in the lactation before the current one increased. The magnitude of this effect was greatest when comparing lactations with no SCC $>199,000$ cells $/ \mathrm{mL}$ to those with $>75 \%$ of SCC $>199,000$ cells $/ \mathrm{mL}(\mathrm{OR}=1.99,1.56-2.53)$.

The odds of cure were 2 times as high in a parity 2 cow compared with a parity 5 plus cow $(\mathrm{OR}=2.00$, 1.79-2.25). Increasing milk yield at drying off was associated with a reduced probability of cure and similar effects on the odds of cure were seen with the explanatory variables lactation length and SCC at last test day before drying off.

Posterior predictions indicated a good model fit. Example predictions of cure probabilities are provided to illustrate the variation in expected cures for 3 hypothetical groups of cows.

- Group 1: $10 \%$ of prior lactation SCC >199,000 cells $/ \mathrm{mL}, 10 \%$ of prior lactation $\mathrm{SCC}>399,000$ cells $/ \mathrm{mL}$, no SCC in lactation before current $>199,000$ cells $/ \mathrm{mL}$, parity $=3$, milk yield at last test day before drying off $=15 \mathrm{~kg}$, lactation length before drying off $=305 \mathrm{~d}$, SCC at last test day before drying off $=250,000$ cells $/ \mathrm{mL}$. Predicted probability of cure across the dry period ( $95 \%$ credible interval $)=0.87(0.83-0.92)$.

- Group 2: $30 \%$ of prior lactation SCC >199,000 cells/mL, $30 \%$ of prior lactation SCC $>399,000$ cells $/ \mathrm{mL}$, no SCC in lactation before current $>199,000$ cells $/ \mathrm{mL}$, parity $=3$, milk yield at last test day before drying off $=20 \mathrm{~kg}$, lactation length before drying off $=320 \mathrm{~d}$, SCC at last test day before drying off $=700,000$ cells $/ \mathrm{mL}$. Predicted probability of cure across the dry period $(95 \%$ credible interval $)=0.81(0.73-0.88)$.

- Group 3: $80 \%$ of prior lactation SCC $>199,000$ cells $/ \mathrm{mL}, 80 \%$ of prior lactation $\mathrm{SCC}>399,000$ cells $/ \mathrm{mL}, 80 \%$ of lactation before current $>199,000$ cells $/ \mathrm{mL}$, parity $=5$, milk yield at last test day before drying off $=25 \mathrm{~kg}$, lactation length before drying off $=350 \mathrm{~d}$, SCC at last test day before drying off $=200,000$ cells $/ \mathrm{mL}$. Predicted probability of cure across the dry period (95\% credible interval $)=0.38(0.13-0.75)$.

Posterior predictions indicated a good model fit.

Model 2: New IMI. The results of this model are presented in Table 4. The probability of new IMI in a cow was significantly increased as the proportion of SCC >199,000 cells/mL in the lactation before the current one increased. The odds of new IMI were 0.51 times (credible interval $=0.36-0.70$ ) as likely if $\leq 25 \%$ of the prior lactation was $>199,000$ cells $/ \mathrm{mL}$ and nearly 0.36 times (credible interval $=0.26-0.50$ ) as likely if no SCC $>199,000$ cells $/ \mathrm{mL}$ when compared with a lactation where $>75 \%$ of $\mathrm{SCC}>199,000$ cells $/ \mathrm{mL}$.

The odds of new IMI were 0.65 times lower in a parity 2 cow compared with an equivalent parity 5 plus cow (credible interval $=0.59-0.71)$. Increasing milk yield at drying off was associated with an increased

Table 4. Model 2: Results of the multilevel logistic regression model for the probability of new IMI in an individual cow across the dry period

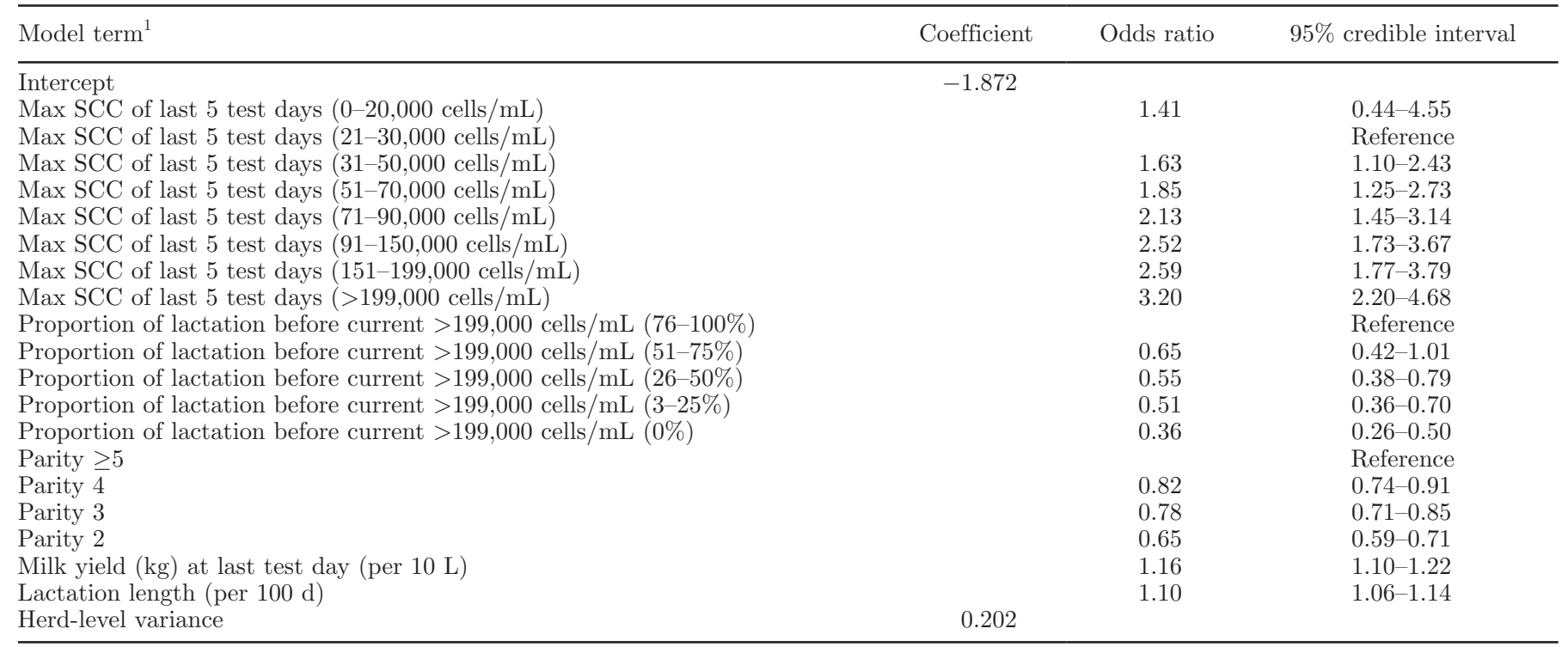

${ }^{1}$ Maximum SCC last 5 test days $=$ the categorized maximum SCC of the last 5 test days before drying off; Parity $\geq 5=$ includes parity $5-16$. 
probability of new IMI and similar effects on the odds of new IMI were seen with the explanatory variable lactation length.

The predicted odds of new IMI was increased as the maximum SCC of the last 5 test days increased relative to a lactation with a maximum of 21,000 to 30,000 cells/mL. An extremely low SCC of $\leq 20,000$ cells $/ \mathrm{mL}$ as the maximum of the last 5 test days had an increased probability of a new IMI relative to a SCC of 21,000 to 30,000 cells $/ \mathrm{mL}$, though this was not significant $(\mathrm{OR}=$ 1.44, 0.44-4.55). Posterior predictions indicated a good model fit.

\section{DISCUSSION}

The cure and new IMI models produced predictions that discriminated well between cows in different risk categories. These findings demonstrate that lifetime cow records can be used successfully to predict whether individual cows are more or less likely to cure or develop a new IMI during the dry period.

\section{Cure of IMI}

Mean cure across the data set compared closely to a previous UK study using SCC data where mean cure was $72 \%$, median $72.7 \%(\mathrm{IQR}=63.6-81.5 \%$; Madouasse et al., 2010). This was higher than mean cure of $62.9 \%$ (median 62.4\%) in a study of 145 Wisconsin herds (Cook et al., 2002). Cure was significantly associated with an increasing proportion of the current lactation and lactation before the current spent infected. Increasing log SCC, age, and number of quarters infected has been found to decrease predicted probability of cure (Sol et al., 1994), as has increased geometric mean natural log of the last 3 test days for composite SCC (Osterås et al., 1999). However, no previous studies have used earlier lactation records to create risk profiles for dry period outcome. A novel finding of our study is the effect of high SCC in earlier lactations, which suggests that infections either survive through sequential dry periods or that some cows are susceptible to repeated chronic infections. However, this observation is based only on SCC as a proxy for infection and does not take into account the fact that these elevations of SCC across a time period may be the result of different bacterial pathogens rather than the same persistent infection.

Increased SCC at last test decreased the odds of cure and this concurs with a previous study, which reported that individual SCC $>199,000$ cells $/ \mathrm{mL}$ at $\leq 60 \mathrm{~d}$ before drying off was significantly associated with IMI within $30 \mathrm{~d}$ of calving (Green et al., 2008). Higher milk yield at last test was associated with a lower odds of cure though little evidence exists on the influence of yield at drying off on cure.

Increased lactation length resulted in a lower odds of cure though the mechanism behind this is unclear. However, a longer lactation may result in the acquisition of longer term chronic infections that become more difficult to cure (Green et al., 2007). Lower parity was associated with greater odds of cure, though research suggests this effect is inconsistent (Dingwell et al., 2003; Newman et al., 2010; Pinedo et al., 2012).

\section{New IMI}

Mean new infection rates were comparable to previous UK work with a mean of $17.9 \%$, median $16.7 \%$ $(\mathrm{IQR}=11.1-23.3 \%$; Madouasse et al., 2010), though lower than the mean of $22.4 \%$ (median 22.1\%) in a study of 145 Wisconsin herds (Cook et al., 2002). Higher milk yield at last test was associated with higher odds of new infection and is in agreement with previous studies (Huxley et al., 2002; Rajala-Schultz et al., 2005; Newman et al., 2010). Higher milk yield may increase intramammary pressure, milk leakage (Cousins et al., 1980; Schukken et al., 1993), dilute protective factors (immunoglobulins), delay keratin plug formation (making new infection more likely; Dingwell et al., 2004), or could be linked to genetic merit and cows tending toward a higher risk of negative energy balance and concurrent immunosuppression at next calving.

Increased odds of new infection was associated with increased DIM at last test, which may lead to overconditioned individuals at greater risk of immunosuppression and new infection in the periparturient period. Lower parity cows had a lower odds of new infection, which is in agreement with studies reporting increasing parity being associated with the occurrence of new infection in the dry period (Dingwell et al., 2004; Madouasse et al., 2012). With increasing parity, efficacy of anatomical or immune defenses reduce (Cousins et al., 1980) and risk of new infections increases (Paganelli et al., 2006; Weng, 2006; Green et al., 2007).

Probability of new infection significantly increased as the proportion of $\mathrm{SCC}>199,000$ cells $/ \mathrm{mL}$ in the lactation before the current one increased. This was surprising, however, as one hypothesis for this may be that it is a marker of susceptibility to infection; cows with previous infections that apparently cure may be more susceptible to future new infections. Very low SCC (0-20,000 cells $/ \mathrm{mL})$ before drying off tended toward an increased odds of new infection. However, this association was not significant and should be interpreted with caution. Low SCC has been associated with increased risk and severity of clinical mastitis and 
we hypothesize that very low SCC (0-20,000 cells/mL) before drying off may be a risk factor for the development of new IMI in the dry period (Suriyasathaporn et al., 2000; Peeler et al., 2003). An optimal microbiome in the mammary gland is associated with a SCC in milk of between 21,000 and 30,000 cells/mL and has been proposed to provide a protective effect (Oikonomou et al., 2012, 2014).

Knowledge of a risk profile for cure or new infections across the dry period for individual cows could be of practical use on farm. In cows unlikely to cure across the dry period, care could be exercised after calving, before the first recording of SCC, such that potentially infected cows may be segregated during milking or handled with care in the milking parlor, not given access to yards where cross suckling by calves could occur (Green et al., 2007), and considered for subsequent culling subject to infection status being confirmed in the next lactation (Sol et al., 1994; Dingwell et al., 2003).

In cows likely to develop new infections across the dry period, interventions should be targeted at environmental hygiene, milk yield at dry off, or dry cow therapy (Green et al., 2007, 2008; Halasa et al., 2009a,b). Farm decision support tools to calculate risk of new infections or cures could therefore be beneficial as an aid to management.

\section{REFERENCES}

Archer, S. C., F. Mc Coy, W. Wapenaar, and M. J. Green. 2013a. Association between somatic cell count early in the first lactation and the lifetime milk yield of cows in Irish dairy herds. J. Dairy Sci. 96:2951-2959. http://dx.doi.org/10.3168/jds.2012-6294.

Archer, S. C., F. Mc Coy, W. Wapenaar, and M. J. Green. 2013b, Association between somatic cell count early in the first lactation and the longevity of Irish dairy cows. J. Dairy Sci. 96:2939-2950. http://dx.doi.org/10.3168/jds.2012-6115.

Archer, S. C., F. Mc Coy, W. Wapenaar, and M. J. Green. 2014. Association between somatic cell count during the first lactation and the cumulative milk yield of cows in Irish dairy herds. J. Dairy Sci. 97:2135-2144. http://dx.doi.org/10.3168/jds.2013-7158.

Bradley, A. J., and M. J. Green. 2000. A study of the incidence and significance of intramammary enterobacterial infections acquired during the dry period. J. Dairy Sci. 83:1957-1965. http://dx.doi. org/10.3168/jds.S0022-0302(00)75072-7.

Church, G. T., L. K. Fox, C. T. Gaskins, D. D. Hancock, and J. M Gay. 2008. The effect of a shortened dry period on intramammary infections during the subsequent lactation. J. Dairy Sci. 91:42194225. http://dx.doi.org/10.3168/jds.2008-1377.

Coffey, T. J., G. D. Pullinger, R. Urwin, S. M. Wilson, M. C. Maiden, and J. A. Leigh. 2006. First insights into the evolution of Streptococcus uberis: A multilocus sequence typing scheme that enables investigation of its population biology. Appl. Environ. Microbiol. 72:1420-1428. http://dx.doi.org/10.1128/AEM.72.2.14201428.2006 .

Cook, N. B., T. B. Bennett, K. M. Emery, and K. V. Nordlund. 2002. Monitoring nonlactating cow intramammary infection dynamics using DHI somatic cell count data. J. Dairy Sci. 85:1119-1126. http://dx.doi.org/10.3168/jds.S0022-0302(02)74173-8.

Cousins, C. L., T. M. Higgs, E. R. Jackson, F. K. Neave, and F. H. Dodd. 1980. Susceptibility of the bovine udder to bacterial infection in the dry period. J. Dairy Res. 47:11-18.
Dingwell, R. T., K. E. Leslie, T. F. Duffield, Y. H. Schukken, L. DesCoteaux, G. P. Keefe, D. F. Kelton, K. D. Lissemore, W. Shewfelt, P. Dick, and R. Bagg. 2003. Efficacy of intramammary tilmicosin and risk factors for cure of Staphylococcus aureus infection in the dry period. J. Dairy Sci. 86:159-168. http://dx.doi.org/10.3168/ jds.S0022-0302(03)73596-6.

Dingwell, R. T., K. E. Leslie, Y. H. Schukken, J. M. Sargeant, L. L. Timms, T. F. Duffield, G. P. Keefe, D. F. Kelton, K. D. Lissemore, and J. Conklin. 2004. Association of cow and quarter-level factors at drying-off with new intramammary infections during the dry period. Prev. Vet. Med. 63:75-89. http://dx.doi.org/10.1016/j. prevetmed.2004.01.012.

Dohoo, I. R., and K. E. Leslie. 1991. Evaluation of changes in somatic cell counts as indicators of new intramammary infections. Prev. Vet. Med. 10:225-237. http://dx.doi.org/10.1016/01675877(91)90006-N.

Eberhart, R. J. 1986. Management of dry cows to reduce mastitis. J. Dairy Sci. 69:1721-1732. http://dx.doi.org/10.3168/jds.S00220302(86)80591-4.

Farm Animal Welfare Council. 2009. Opinion on the Welfare of the Dairy Cow. Accessed Apr. 7, 2016. https://www.gov. uk/government/uploads/system/uploads/attachment_data/ file/325044/FAWC_opinion_on_dairy_cow_welfare.pdf.

Gelman, A., X.-L. Meng, and H. Stern. 1996. Posterior predictive assessment of model fitness via realized discrepancies. Stat. Sin. 6:733-807.

Green, M. J., A. J. Bradley, G. F. Medley, and W. J. Browne. 2007. Cow, farm, and management factors during the dry period that determine the rate of clinical mastitis after calving. J. Dairy Sci. 90:3764-3776. http://dx.doi.org/10.3168/jds.2007-0107.

Green, M. J., A. J. Bradley, G. F. Medley, and W. J. Browne. 2008 Cow, farm, and herd management factors in the dry period associated with raised somatic cell counts in early lactation. J. Dairy Sci. 91:1403-1415. http://dx.doi.org/10.3168/jds.2007-0621.

Green, M. J., P. R. Burton, L. E. Green, Y. H. Schukken, J. Bradley, E. J. Peeler, and G. F. Medley. 2004. The use of Markov chain Monte Carlo for analysis of correlated binary data: Patterns of somatic cells in milk and the risk of clinical mastitis in dairy cows. Prev. Vet. Med. 64:157-174. http://dx.doi.org/10.1016/j. prevetmed.2004.05.006.

Green, M. J., L. E. Green, G. F. Medley, Y. H. Schukken, and A. J. Bradley. 2002. Influence of dry period bacterial intramammary infection on clinical mastitis in dairy cows. J. Dairy Sci. 85:25892599. http://dx.doi.org/10.3168/jds.S0022-0302(02)74343-9.

Halasa, T., M. Nielen, A. C. Whist, and O. Osterås. 2009a. Metaanalysis of dry cow management for dairy cattle. Part 2. Cure of existing intramammary infections. J. Dairy Sci. 92:3150-3157. http://dx.doi.org/10.3168/jds.2008-1741.

Halasa, T., O. Osterås, H. Hogeveen, T. van Werven, and M. Nielen. 2009b. Meta-analysis of dry cow management for dairy cattle. Part 1. Protection against new intramammary infections. J. Dairy Sci. 92:3134-3149. http://dx.doi.org/10.3168/jds.2008-1740.

Huxley, J. N., M. J. Green, L. E. Green, and J. Bradley. 2002. Evaluation of the efficacy of an internal teat sealer during the dry period. J. Dairy Sci. 85:551-561. http://dx.doi.org/10.3168/jds.S00220302(02)74108-8.

Kossaibati, M. A., and R. J. Esslemont. 1997. The costs of production diseases in dairy herds in England. Vet. J. 154:41-51. http:// dx.doi.org/10.1016/S1090-0233(05)80007-3.

Madouasse, A., J. N. Huxley, W. J. Browne, A. J. Bradley, and M. J. Green. 2010. Somatic cell count dynamics in a large sample of dairy herds in England and Wales. Prev. Vet. Med. 96:56-64. http://dx.doi.org/10.1016/j.prevetmed.2010.05.005.

Madouasse, A., W. J. Browne, J. N. Huxley, F. Toni, A. J. Bradley, and M. J. Green. 2012. Risk factors for a high somatic cell count at the first milk recording in a large sample of UK dairy herds. J. Dairy Sci. 95:1873-1884.http://dx.doi.org/10.3168/jds.2011-4801.

McDermott, M. P., H. N. Erb, and R. P. Natzke. 1982. Predictability by somatic cell counts related to prevalence of intramammary infection within herds. J. Dairy Sci. 65:1535-1539. http://dx.doi org/10.3168/jds.S0022-0302(82)82378-3. 
Newman, K. A., P. J. Rajala-Schultz, F. J. Degraves, and J. Lakritz. 2010. Association of milk yield and infection status at dry-off with intramammary infections at subsequent calving. J. Dairy Res. 77:99-106. http://dx.doi.org/10.1017/S0022029909990380.

Oikonomou, G., M. L. Bicalho, E. Meira, R. E. Rossi, C. Foditsch, V. S. Machado, A. G. V. Teixeira, C. Santisteban, Y. H. Schukken, and R. C. Bicalho. 2014. Microbiota of cow's milk; Distinguishing healthy, sub-clinically and clinically diseased quarters. PLoS ONE 9:e85904. http://dx.doi.org/10.1371/journal.pone.0085904.

Oikonomou, G., V. S. Machado, C. Santisteban, Y. H. Schukken, and R. C. Bicalho. 2012. Microbial diversity of bovine mastitic milk as described by pyrosequencing of metagenomic 16s rDNA. PLoS ONE 7:e47671. http://dx.doi.org/10.1371/journal.pone.0047671.

Osterås, O., V. L. Edge, and S. W. Martin. 1999. Determinants of success or failure in the elimination of major mastitis pathogens in selective dry cow therapy. J. Dairy Sci. 82:1221-1231. http:// dx.doi.org/10.3168/jds.S0022-0302(99)75345-2.

Paganelli, R., A. Di Iorio, A. Cherubini, F. Lauretani, C. Mussi, S. Volpato, M. Abate, G. Abate, and L. Ferrucci. 2006. Frailty of older age: The Role of the endocrine-immune interaction. Curr. Pharm. Des. 12:3147-3159. http://dx.doi.org/10.2174/138161206777947533.

Pantoja, J. C. F., C. Hulland, and P. L. Ruegg. 2009. Somatic cell count status across the dry period as a risk factor for the development of clinical mastitis in the subsequent lactation. J. Dairy Sci. 92:139-148. http://dx.doi.org/10.3168/jds.2008-1477.

Peeler, E. J., M. J. Green, J. L. Fitzpatrick, and L. E. Green. 2003. The association between quarter somatic-cell counts and clinical mastitis in three British dairy herds. Prev. Vet. Med. 59:169-180. http://dx.doi.org/10.1016/S0167-5877(03)00076-X.

Pinedo, P. J., C. Fleming, and C. A. Risco. 2012. Events occurring during the previous lactation, the dry period, and peripartum as risk factors for early lactation mastitis in cows receiving 2 different intramammary dry cow therapies. J. Dairy Sci. 95:7015-7026. http://dx.doi.org/10.3168/jds.2012-5398.

R Core Team. 2015. R: A language and environment for statistical computing. R Foundation for Statistical Computing, Vienna, Austria.

Rabash, J. C., C. Charlton, W.J. Browne, M. Healy, and B. Cameron. 2015. MLwiN Version 2.32. Centre for Multilevel Modelling, University of Bristol, Bristol, UK.
Rajala-Schultz, P. J., Y. T. Gröhn, C. E. McCulloch, and C. L. Guard. 1999. Effects of clinical mastitis on milk yield in dairy cows. J. Dairy Sci. 82:1213-1220. http://dx.doi.org/10.3168/jds.S00220302(99)75344-0.

Rajala-Schultz, P. J., J. S. Hogan, and K. L. Smith. 2005. Short communication: Association between milk yield at dry-off and probability of intramammary infections at calving. J. Dairy Sci. 88:577579. http://dx.doi.org/10.3168/jds.S0022-0302(05)72720-X.

Rajala-Schultz, P. J., A. H. Torres, and F. J. DeGraves. 2011. Milk yield and somatic cell count during the following lactation after selective treatment of cows at dry-off. J. Dairy Res. 78:489-499. http://dx.doi.org/10.1017/S0022029911000690.

Schepers, A. J., T. J. Lam, Y. H. Schukken, J. B. Wilmink, and W. J. Hanekamp. 1997. Estimation of variance components for somatic cell counts to determine thresholds for uninfected quarters. J. Dairy Sci. 80:1833-1840. http://dx.doi.org/10.3168/jds.S00220302(97)76118-6.

Schukken, Y. H., J. Vanvliet, D. Vandegeer, and F. J. Grommers. 1993. A randomized blind trial on dry cow antibiotic infusion in a low somatic cell count herd. J. Dairy Sci. 76:2925-2930. http:// dx.doi.org/10.3168/jds.S0022-0302(93)77632-8.

Sol, J., O. C. Sampimon, J. J. Snoep, and Y. H. Schukken. 1994. Factors associated with bacteriological cure after dry cow treatment of subclinical staphylococcal mastitis with antibiotics. J. Dairy Sci. 77:75-79. http://dx.doi.org/10.3168/jds.S0022-0302(94)76930-7.

Suriyasathaporn, W., Y. H. Schukken, M. Nielen, and A. Brand. 2000. Low somatic cell count: A risk factor for subsequent clinical mastitis in a dairy herd. J. Dairy Sci. 83:1248-1255. http://dx.doi. org/10.3168/jds.S0022-0302(00)74991-5.

Weng, N. P. 2006. Aging of the immune system: How much can the adaptive immune system adapt? Immunity 24:495-499. http:// dx.doi.org/10.1016/j.immuni.2006.05.001.

Whist, A. C., and O. Osterås. 2007. Associations between somatic cell counts at calving or prior to drying-off and clinical mastitis in the remaining or subsequent lactation. J. Dairy Res. 74:66-73. http:// dx.doi.org/10.1017/S0022029906002172. 